\title{
The scavenging of superoxide radicals promotes apoptosis induced by a novel cell-permeable fusion protein, sTRAIL:FeSOD, in tumor necrosis factor-related apoptosis-inducing ligand-resistant leukemia cells
}

\author{
Hongyun Tang ${ }^{1}$, Yong Qin ${ }^{1}$, Jianyong Li ${ }^{1}$, Xingguo Gong ${ }^{2^{*}}$
}

\begin{abstract}
Background: Many cancer cells develop resistance to tumor necrosis factor-related apoptosis-inducing ligand (TRAIL)-induced apoptosis, necessitating combination with chemotherapy, and normal cells manifest side effects due to the combined treatment regimen of TRAIL and chemotherapeutic drugs. A novel cancer therapy utilizing TRAIL is thus urgently needed.

Results: In this study, we exploited TRAIL receptor-mediated endocytosis for the first time to produce a cellpermeable molecule, soluble forms of recombinant TRAlL:iron superoxide dismutase (sTRAIL:FeSOD), which possesses sTRAIL-induced apoptotic ability and FeSOD antioxidant activity. The FeSOD component was rapidly introduced into the cell by sTRAIL and intracellular superoxide radical $\left(\mathrm{O}_{2}{ }^{-}\right)$, which have been implicated as potential modulators of apoptosis in cancer cells, was eliminated, resulting in a highly reduced cellular environment. The decrease in cellular $\mathrm{O}_{2}{ }^{-}$, which was accompanied by a brief accumulation of $\mathrm{H}_{2} \mathrm{O}_{2}$ and downregulation of phosphorylated Akt (p-Akt) and cellular FLICE-inhibitory protein, sensitized K562 leukemia cells and human promyelocytic leukemia ( $\mathrm{HL}-60$ ) cells to TRAlL-induced apoptosis. The low $\mathrm{H}_{2} \mathrm{O}_{2}$ levels protected human LO2 hepatocytes from STRAIL:FeSOD-induced apoptosis despite downregulation of p-Akt. We also obtained evidence that the lack of response to STRAIL:FeSOD in normal T cells occurred because sTRAIL:FeSOD shows much stronger shifts of redox state in erythroleukemia (K562) and HL-60 cells compared to that in normal T cells. K562 and HL-60 cells underwent STRAIL:FeSOD-induced apoptosis without the dysfunction of mitochondria.
\end{abstract}

Conclusions: The fusion protein overcomes the inability of FeSOD to permeate the cell membrane, exhibits synergistic apoptotic effects on $\mathrm{K} 562$ and $\mathrm{HL}-60$ cells and demonstrates minimal toxicity to normal T cells and the normal liver cell line LO2, indicating its potential value for the treatment of leukemia.

\section{Background}

Tumor necrosis factor-related apoptosis-inducing ligand (TRAIL) is a potent anticancer therapeutic agent that induces apoptotic cell death in cancer cells [1], regardless of P53 status. TRAIL is therefore a promising cancer therapeutic agent, especially for chemotherapy- or radiotherapy-resistant cancer cells [2]. Preclinical studies

\footnotetext{
* Correspondence: xingguogong@163.com

${ }^{2}$ Institute of Biochemistry, College of Life Sciences, Zijingang campus, Room

345, Zhejiang University, Hangzhou, PR China

Full list of author information is available at the end of the article
}

in mice and nonhuman primates with soluble forms of recombinant TRAIL (sTRAIL) have shown strong tumoricidal activity in xenografted tumor models without apparent toxic side effects [3,4]. However, certain TRAIL preparations have been shown to be toxic to human hepatocytes and keratinocytes, which may be responsible for the considerable hepatotoxicity or fulminant hepatic failure observed in human trials [5,6]. In addition, TRAIL resistance has been observed in many cancer cells [7-9]. Thus, understanding the exact molecular determinants of TRAIL resistance and developing strategies to overcome 
such resistance without killing normal cells are extremely important prerequisites for the successful deployment of TRAIL as a therapeutic agent.

Several different kinds of chemotherapy drugs are used in combination with TRAIL to sensitize TRAILresistant cancer cells, and many reports have combined recombinant TRAIL with standard anticancer therapies to induce synergistic tumor cell apoptosis $[10,11]$. However, there is evidence that some normal human cells are sensitive to apoptosis after treatment by TRAIL in combination with chemotherapeutic drugs $[12,13]$. Furthermore, mutation or deletion of $p 53$ occurs in more than half of all human tumors, and Akt is frequently hyperactive in cancer cells. Both of these alterations play a prominent role in cell resistance to chemoradiotherapy. Edwin et al. [14] reported a recombinant fusion protein, single-chain variable fragment 425 (scFv425):sTRAIL, that combined the tumoricidal effect of epidermal growth factor receptor signal inhibition with target cell-restricted apoptosis induction, hence showing promising antitumor activity. Thus, in recent years, biological mechanism-based cancer therapeutic strategies that may exert enhanced antitumor activity and high tumor specificity have attracted much more attention because of the unfavorable side effects of chemoradiotherapy and the resistance of many tumor cells to chemo- or radiotherapy $[2,15]$.

Antioxidants have long been used for the treatment of cancer, especially in combination with other anticancer drugs [16]. Superoxide dismutase (SOD) is a type of potent antioxidant enzyme that suppresses the growth of various cancer cells by removing superoxide radicals $\left(\mathrm{O}_{2}{ }^{-}\right)$[17], which are critical in different stages of carcinogenesis. However, owing to its large molecular weight, SOD cannot enter the cell to exert its effects. To overcome this deficiency, a liposome can be used to enclose SOD, allowing it to enter cells [18]. Additionally, we have previously shown that a fusion of SOD with $\mathrm{scFv}$ was able to permeate the cell membrane via receptormediated endocytosis and was able to then inhibit cell proliferation through the Akt/p2 $7^{\mathrm{kip} 1}$ pathway [19]. However, neither of these approaches effectively inhibits cancer cell proliferation, and therefore engineering SOD to permeate the cell membrane and exercise its powerful cytotoxic effects is key to its clinical application.

Akt regulates the transactivation of antiapoptotic molecules such as cellular FLICE-inhibitory protein (cFLIP $_{\mathrm{L}}$ ), $\mathrm{X}$-linked inhibitor of apoptosis protein and the antiapoptotic protein B-cell lymphoma-extra large (Bcl$\mathrm{x}_{\mathrm{L}}$ ) [20-22]. Furthermore, Akt is dephosphorylated at Thr308 (converting it into the inactive form) at reduced levels of intracellular reactive oxygen species (ROS) [23], making SOD an attractive therapeutic agent for sensitizing cancer cells to TRAIL-induced apoptosis. Because
TRAIL can be internalized via receptor-mediated endocytosis [24], we hypothesized that iron superoxide dismutase (FeSOD) could be internalized with sTRAIL to reduce the level of intracellular $\mathrm{O}_{2}{ }^{-}$. Here we cloned and coexpressed sTRAIL (114 to 281 aa) and FeSOD, as well as a fusion protein containing both, to determine whether the resultant fused protein possessed dual activity and could exert a synergistic effect on cancer cells. We observed sTRAIL:FeSOD to engage the TRAIL receptors (TRAIL-R1 and TRAIL-R2), resulting in internalization of the receptor and ligand. Once inside the cell, sTRAIL:FeSOD scavenged intracellular $\mathrm{O}_{2}{ }^{-}$, which then influenced the TRAIL-induced apoptosis pathway.

\section{Results}

\section{Production of sTRAIL:FeSOD}

After addition of isopropyl- $\beta$-D-thiogalactoside (IPTG), the expected proteins sTRAIL (21.6 kDa), enzymatic activity deficient form of fused protein (sTRAIL:mFeSOD) $(42.6 \mathrm{kDa})$ and sTRAIL:FeSOD (42.6 kDa) were recovered as demonstrated by Western blot analysis with an antiTRAIL antibody (Figure 1A). The sTRAIL:FeSOD and sTRAIL:mFeSOD proteins were expressed in inclusion bodies and required refolding to regain activity. The trimeric structure is the basis of sTRAIL-induced apoptotic function. To determine whether the FeSOD domain changes the oligomerization state of sTRAIL, renatured sTRAIL:FeSOD was collected and run over a Sephadex G-100 column (GE Healthcare, Fairfield, Connecticut, USA). The renatured proteins were identified to be homogeneous (data not shown). Renatured sTRAIL:FeSOD was further shown to be trimeric by performing native polyacrylamide gel electrophoresis (PAGE) Western blot analysis (Figure 1B). SOD activity assays indicated that the antioxidant activity of renatured sTRAIL:FeSOD was 2,300 $\mathrm{U} / \mathrm{mg}$, whereas that of natural Nostoc commune FeSOD was $3,500 \mathrm{U} / \mathrm{mg}$. sTRAIL:mFeSOD show no antioxidant activity. The induction of apoptosis in TRAIL-sensitive LO2 cells indicated sTRAIL activity. To exclude the effects of FeSOD, the LO2 cells were incubated in RPMI 1640 medium with $0.25 \mathrm{M}$ sucrose, a condition in which internalization was inhibited (Figure 2D) [25]. The sTRAIL activity assay results are shown in Figure 1C. LO2 cells treated in hyperosmotic medium with $500 \mathrm{ng} / \mathrm{ml}$ sTRAIL showed a $57.2 \%$ cell death rate, whereas sTRAIL:FeSOD and sTRAIL:mFeSOD treated with $1,000 \mathrm{ng} / \mathrm{ml}$ sTRAIL had cell death rates of $48.3 \%$ and $41.5 \%$, respectively.

\section{Sensitization of K562 and HL-60 cell lines to sTRAIL: FeSOD}

As described above, many tumor cells are resistant to TRAIL because of phosphorylated Akt (p-Akt) upregulation. Recently, we discovered that FeSOD can downregulate the levels of p-Akt [19], and therefore we were 


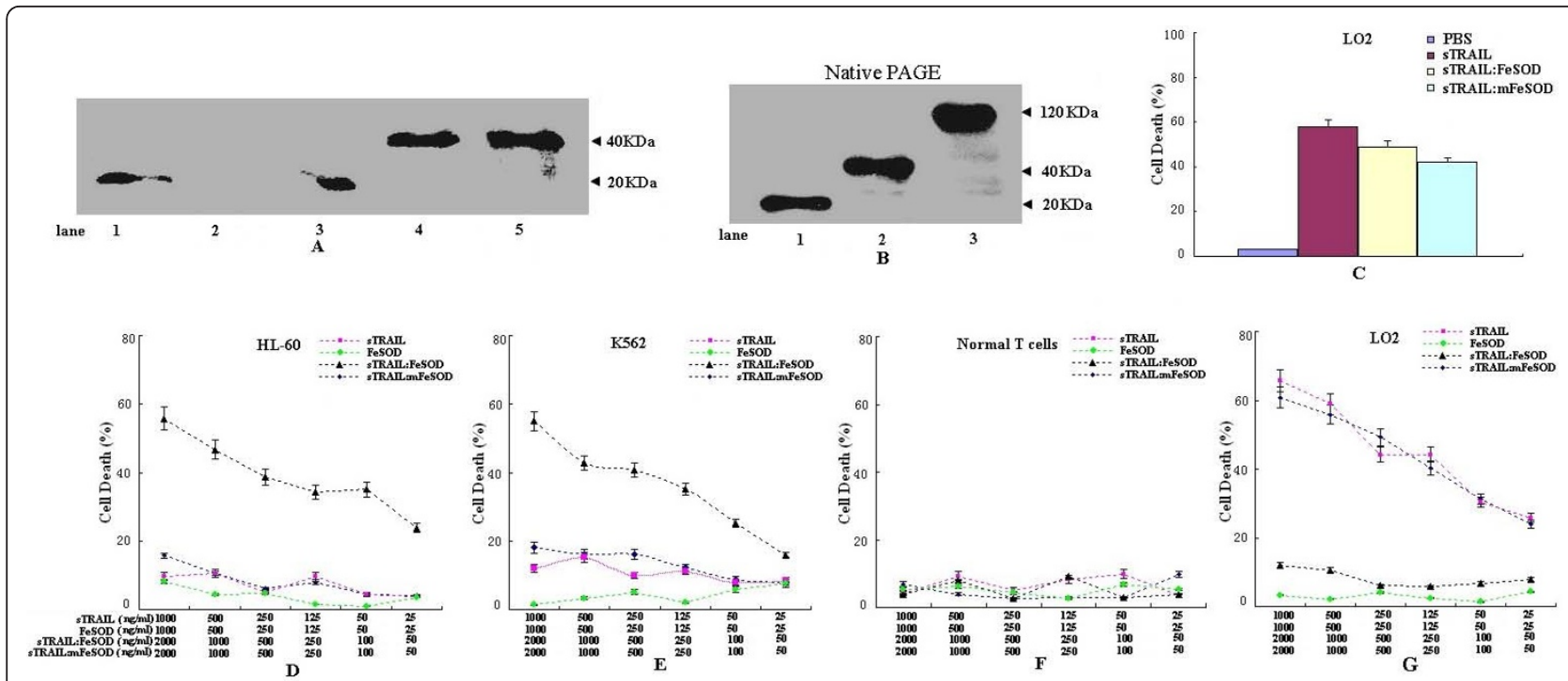

Figure 1 Western blot analysis of soluble forms of recombinant tumor necrosis factor-related apoptosis-inducing ligand (sTRAIL), enzymatic activity deficient form of fused protein (sTRAIL:mFeSOD) and sTRAIL:iron superoxide dismutase (FeSOD) expression and sTRAIL:FeSOD-induced cell death. (A) After isopropyl- $\beta$-D-thiogalactoside induction, the expressed sTRAIL, sTRAIL:mFeSOD or sTRAIL:FeSOD was subjected to Western blot analysis with anti-TRAIL antibody. Lanes 1 to 5 are sTRAIL control (Peprotech, Rocky Hill, New Jersey, USA) and extracts of BL-21 transformed with pET28, pET28-sTRAIL, pET28-STRAIL:mFeSOD and pET28-sTRAIL:FeSOD, respectively. (B) Samples were prepared and electrophoresed using native polyacrylamide gel electrophoresis (PAGE) under nondenaturing conditions followed by electrotransfer and immunoblotting with TRAIL antibody. Lanes 1 to 3 are sTRAIL control (purchased from Peprotech), sTRAIL:FeSOD (before renaturation) and STRAIL:FeSOD (renatured), respectively. (C) Six-well plates were seeded with LO2 cells and allowed to adhere before replacement with RPMI 1640 medium with hyperosmotic sucrose $(0.25 \mathrm{M})$ containing sTRAIL $(500 \mathrm{ng} / \mathrm{ml})$ ), sTRAll:FeSOD $(1,000 \mathrm{ng} / \mathrm{ml})$ or sTRAll:mFeSOD $(1,000 \mathrm{ng} / \mathrm{ml})$. After treatment for 8 hours, cell death was quantified by flow cytometry. (D) through (G) Cells were grown in six-well plates to 60\% confluence, and the indicated proteins were added at the indicated concentrations. After treatment for 8 hours, cells were stained with fluorescein isothiocyanate anti-annexin $\vee$ antibody and propidium iodide and then examined using flow cytometric analysis. For each sample, 10,000 events were acquired. Results are expressed as the mean fluorescence intensity. Each bar represents the mean \pm SE obtained from three independent experiments.

interested in determining whether FeSOD could cooperate with TRAIL to enhance the killing of tumor cells. To address this question, the TRAIL-resistant erythroleukemia (K562) cells and human promyelocytic leukemia (HL-60) cells [26] were used to detect the antitumor ability of sTRAIL:FeSOD. Compared with sTRAIL:mFeSOD or sTRAIL, K562 and HL-60 cells demonstrated significantly less viability after treatment with STRAIL:FeSOD, and their antitumor activity increased significantly in a sTRAIL:FeSOD dosedependent manner. The decrease in cell viability was ascribed to apoptosis as demonstrated by anti-annexin $\mathrm{V}$ antibody and propidium iodide (PI) staining (Figures $1 \mathrm{D}$ and $1 \mathrm{E}$ ), strongly suggesting that sTRAIL and FeSOD synergistically induced apoptosis in the TRAILresistant K562 and HL-60 tumor cells. In contrast to the effect in these two cell lines, sTRAIL:FeSOD did not sensitize freshly isolated peripheral blood $\mathrm{T}$ cells to death induced by apoptosis (Figure 1F). As TRAIL induces apoptosis in normal human hepatocytes, the LO2 cells were also treated as a control group. Interestingly, the LO2 cells, which are extremely sensitive to
TRAIL-induced apoptosis [5], were less sensitive to sTRAIL:FeSOD (Figure 1G).

\section{Rapid internalization of sTRAIL:FeSOD}

The ability of sTRAIL:FeSOD to enter the cell is the basis for the synergistic effect of sTRAIL and FeSOD. After incubation with labeled sTRAIL:FeSOD for 5 minutes, the $\mathrm{K} 562$ cells began to show fluorescence (Figure 2A). Internalization increased at 15 minutes (Figure 2B) with marked fluorescence and fluorescence was even stronger by 30 minutes (Figure 2C). As the cell surface-associated ligand was stripped by acid washing, the internal fluorescence of the cells could be determined. Uptake of sTRAIL:FeSOD was completely blocked by hypertonic medium in LO2 cells (Figure 2D). Quantitative data detected by flow cytometry indicated internalization rates for FeSOD, sTRAIL:mFeSOD and sTRAIL:FeSOD of $1.38 \%, 82.56 \%$ and $85.43 \%$, respectively (Figures $2 \mathrm{E}$ to $2 \mathrm{H})$. Internalization of sTRAIL:FeSOD in HL-60 and LO2 cells, which underwent the same treatment processes as did the K562 cells, were confirmed by LSCM. However, normal $\mathrm{T}$ cells showed low fluorescence 

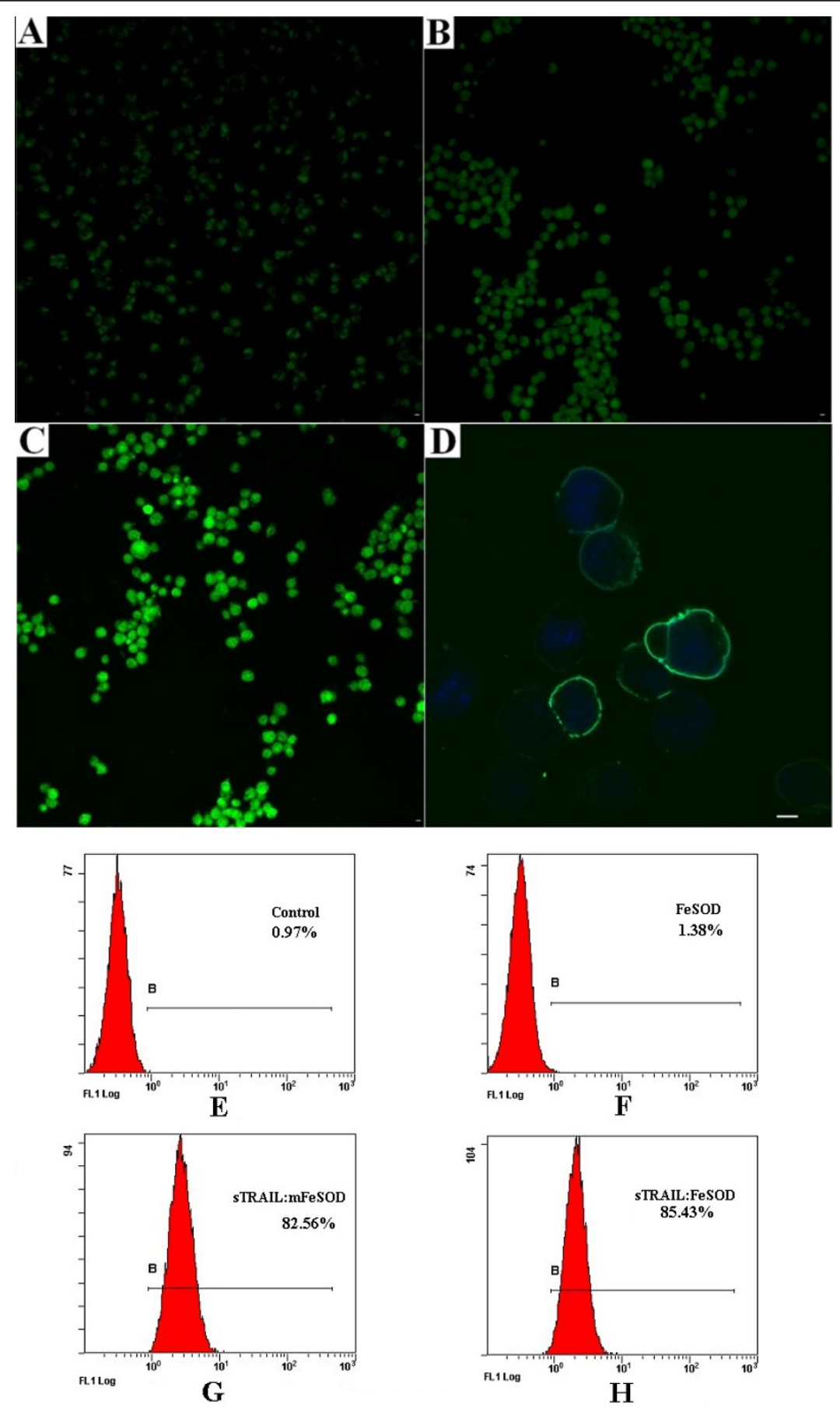

Figure 2 Internalization of soluble forms of recombinant tumor necrosis factor-related apoptosis-inducing ligand:iron superoxide dismutase (sTRAIL:FeSOD) is rapid and is inhibited by hyperosmotic sucrose. (A) through (C) Suspended erythroleukemia (K562) cells were treated with fluorescein isothiocyanate (FITC)-labeled sTRAIL:FeSOD (green) in RPMI 1640 medium without fetal calf serum for (A) 5 minutes, (B) 15 minutes or (C) 30 minutes. After acid washes, cells were visualized with laser scanning confocal microscopy (LSCM). The LSCM parameters were set to an excitation wavelength of $488 \mathrm{~nm}$, an emission wavelength of 500 to $550 \mathrm{~nm}$ and pinhole of $202 \mu \mathrm{m}$. (D) LO2 cells were preincubated for 30 minutes in the presence of $0.25 \mathrm{M}$ sucrose at $37^{\circ} \mathrm{C}$ before incubation in the presence of FITC-labeled sTRAIL:FeSOD (green) for an additional 30 minutes. After being washed extensively in ice-cold phosphate-buffered saline (PBS), cells were counterstained with Hoechst 33342 (blue) and analyzed by LSCM. The white bar represents $5 \mu \mathrm{m}$. The LSCM parameters for FITC were set to an excitation wavelength of 488 $\mathrm{nm}$, an emission wavelength of 500 to $550 \mathrm{~nm}$ and pinhole of $215 \mu \mathrm{m}$. For Hoechst 33342, the parameters were set to an excitation wavelength of $350 \mathrm{~nm}$, an emission wavelength of 460 to $480 \mathrm{~nm}$ and pinhole of $215 \mu \mathrm{m}$. (E-H) After K562 cells were treated with PBS, FITC-labeled FeSOD, STRAIL:FeSOD or STRAIL:mFeSOD for 30 minutes, the internalization rate was quantified by flow cytometry. 
signals, which may be related to the minimal expression of TRAIL death receptors [27] (data not shown).

\section{sTRAIL:FeSOD neutralizes free radical $\mathrm{O}_{2}{ }^{-}$and reduces ROS}

SOD is a potent antiradical enzyme, and Akt activity can be downregulated under low levels of ROS. To investigate the intracellular antioxidant activity of sTRAIL: FeSOD, we measured ROS levels using the oxidationsensitive fluorescent dyes dichlorodihydrofluorescein diacetate (DCFDA) (for total ROS) and dihydroethidium (DHE) (for $\mathrm{O}_{2}{ }^{-}$). The $\mathrm{O}_{2}{ }^{-}$and $\mathrm{ROS}$ levels in leukemia cells decreased significantly after pretreatment with sTRAIL:FeSOD (Figures 3A and 3B). However, in contrast to the phosphate-buffered saline (PBS) control, pretreatment with sTRAIL:mFeSOD or FeSOD did not cause a significant difference in these roles, ruling out a role for sTRAIL in $\mathrm{O}_{2}{ }^{-}$quenching and confirming the low permeability of SOD.

SOD is well known to induce $\mathrm{H}_{2} \mathrm{O}_{2}$ production during $\mathrm{O}_{2}{ }^{-}$scavenging, and therefore we monitored the changes in $\mathrm{H}_{2} \mathrm{O}_{2}, \mathrm{O}_{2}^{-}$, ROS and glutathione (GSH) levels after treating the cells with sTRAIL:FeSOD. As shown in Figures $3 \mathrm{C}$ to $3 \mathrm{~F}, \mathrm{H}_{2} \mathrm{O}_{2}$ levels increased 1 or 2 hours after administration of sTRAIL:FeSOD in K562 and HL-60 cells in comparison with the levels in LO2 and $\mathrm{T}$ cells. However, at 3 hours after treatment, we observed that $\mathrm{H}_{2} \mathrm{O}_{2}$ levels had declined almost to normal levels. As compared with sTRAIL:mFeSOD, sTRAIL:FeSOD induced a notably more significant decrease in cellular $\mathrm{ROS}$ and $\mathrm{O}_{2}{ }^{-}$fluorescence intensities and a marked rise in GSH levels in the K562 and HL-60 cells (Figures 3C to $3 F)$. Figure $3 \mathrm{G}$ shows that the redox status in LO2 cells changed, but not as strongly as they did in the cancer cells or in the sTRAIL:mFeSOD-treated LO2 cells. As shown in Figure $3 \mathrm{H}$, normal $\mathrm{T}$ cells maintained a stable redox status, which may explain why they did not undergo sTRAIL:FeSOD-induced apoptosis. Figure 3I shows that sTRAIL:mFeSOD-induced apoptosis in LO2 cells was accompanied by a rapid increase in ROS levels. The graph also shows that 3 hours after sTRAIL:FeSOD treatment in the two leukemia cell lines, ROS levels did not increase along with the decrease in $\mathrm{H}_{2} \mathrm{O}_{2}$, suggesting that $\mathrm{H}_{2} \mathrm{O}_{2}$ was broken down by the cellular antioxidant defenses rather than giving rise to highly reactive hydroxyl radicals [28].

\section{sTRAIL:FeSOD-induced apoptosis does not involve the mitochondrial apoptotic pathway}

One parameter that is altered by the ROS production is mitochondrial membrane potential $(\Delta \Psi \mathrm{m})$, and cancer cells display a strong resistance to chemotherapeutic agents, which is probably due to their efficacious protection against the mitochondrial apoptotic pathway. To examine the role of the mitochondrial apoptotic pathway in K562 and HL-60 cells undergoing sTRAIL: FeSOD-induced apoptosis, $\Delta \Psi \mathrm{m}$ was analyzed by flow cytometry. Figures $4 \mathrm{~A}$ and $4 \mathrm{~B}$ show an increase in rhodamine123 (Rh123) and JC-1 fluorescence intensity in all four cell lines except the normal $\mathrm{T}$ cells after treatment with sTRAIL:FeSOD, indicating that the mitochondria remained polarized during apoptosis in $\mathrm{K} 562$ and HL-60 cells. The lack of a significant change in Rh123 and JC-1 fluorescence intensity in normal T cells may be related to the stable redox status (Figures $3 \mathrm{H}$ and $3 \mathrm{~J})$. The data shown in Figure $4 \mathrm{C}$ imply that low levels of ROS and high levels of GSH maintain the $\Delta \Psi \mathrm{m}$ and that hyperpolarized mitochondria can reduce ROS to a lower level. Cytochrome c release did not occur during sTRAIL:FeSOD-induced apoptosis (Figure 4D). LO2 are type II cells, and sTRAIL was able to apoptose the LO2 cells in the presence of mitochondrial dysfunction (Figures 1G, 4A and 4B).

\section{sTRAIL:FeSOD-induced death is dependent on caspase-8}

A common feature of cell death through apoptosis is the activation of caspases. The inhibition of caspase- 8 expression effectively protected $\mathrm{K} 562$ and HL-60 cells from sTRAIL:FeSOD-induced apoptosis (Figures 5A and $5 \mathrm{~B})$. This result indicates that STRAIL:FeSODinduced apoptosis is dependent on caspase activation and that caspase- 8 acts as the major initiator caspase in sTRAIL:FeSOD-induced apoptosis in these cells (Figures $5 \mathrm{C}$ to $5 \mathrm{E}$ ). In contrast, decreased expression of caspase-9 did not significantly suppress STRAIL: FeSOD-induced apoptosis in the leukemia cells (Figures 5A and 5B), suggesting the apoptosis to be caspase-9-independent. Changes in caspase-8 and caspase- 3 activity in the two leukemia cell lines were markedly greater than those in the LO2 and T cells (Figure 5C), mirroring the different fate of the four cell lines after treatment with sTRAIL:FeSOD. In contrast to the control, there was no obvious change in caspase- 9 activity in any of the four cell types.

\section{The internalization of FeSOD is indispensable for sTRAIL: FeSOD-induced apoptosis}

First, we examined the expression of TRAIL receptors and whether treatment with STRAIL:FeSOD led to elevated surface expression of DR4 and DR5. No major differences were found in the expression of either DR4 or DR5 after 6 hours of sTRAIL:FeSOD treatment (Figure 5F). To determine which receptor is involved in the death induced by STRAIL:FeSOD and to discern whether the uptake of sTRAIL:FeSOD is receptordependent, we then performed an experiment in which we added blocking antibodies against DR5 and/or DR4 for 1.5 hours prior to sTRAIL:FeSOD exposure [29]. 

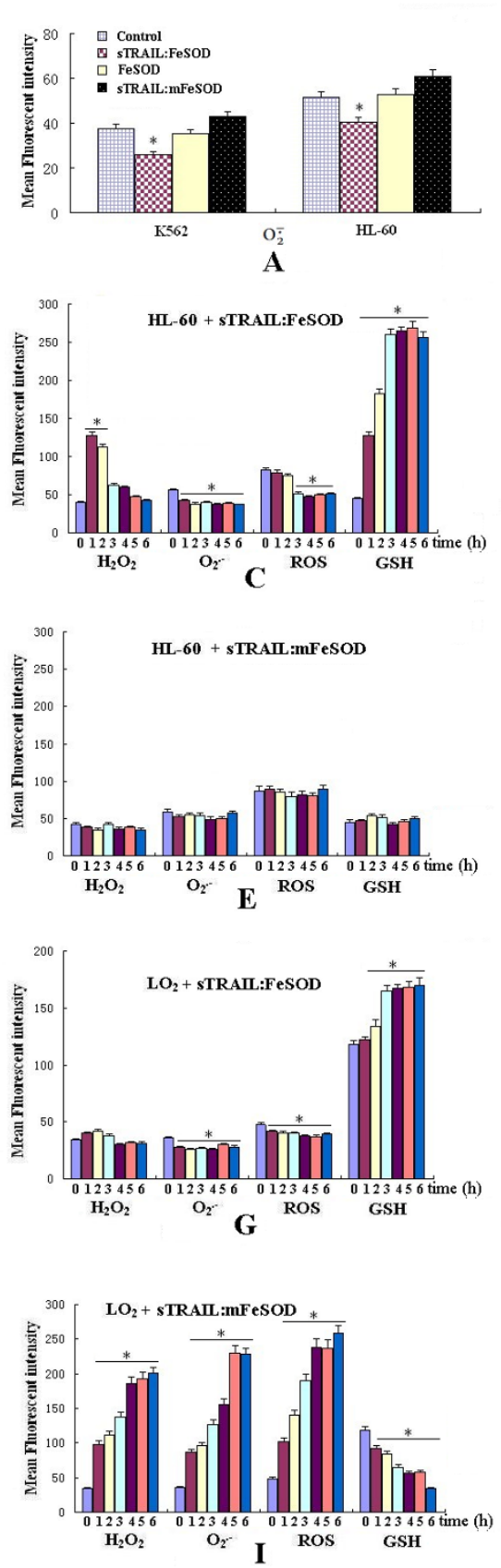
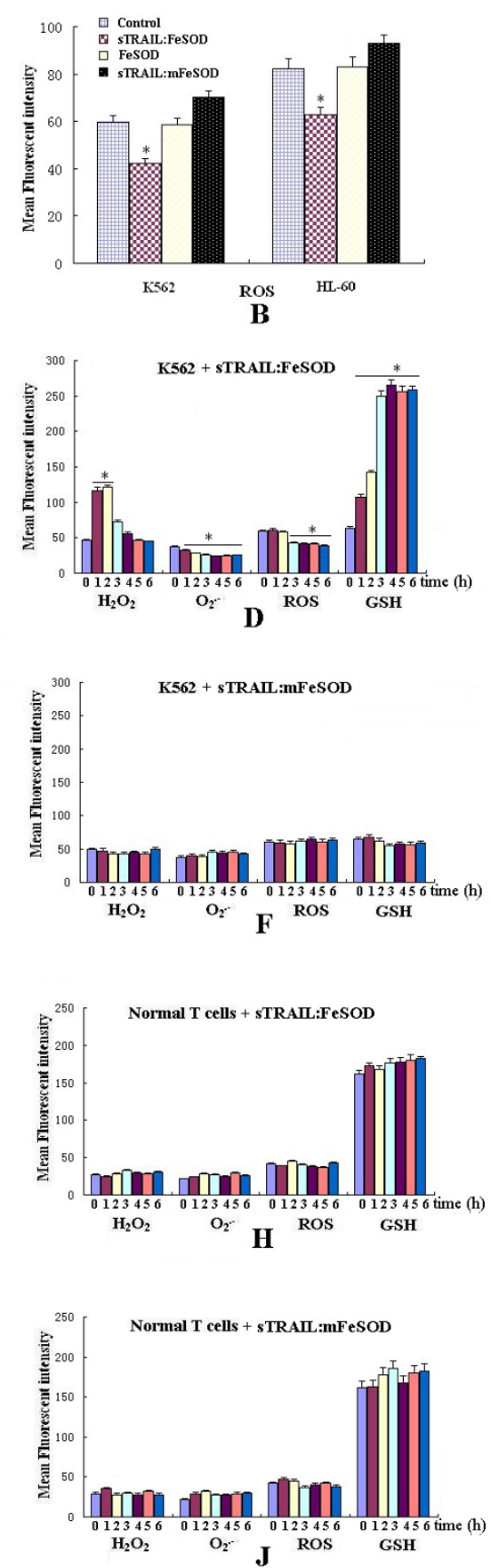

Figure 3 Effects of soluble forms of recombinant tumor necrosis factor-related apoptosis-inducing ligand:iron superoxide dismutase (sTRAIL:FeSOD) on intracellular $\mathrm{H}_{2} \mathrm{O}_{2}$, glutathione $(\mathrm{GSH})$, superoxide radical $\left(\mathrm{O}_{2}{ }^{-}\right)$and reactive oxygen species (ROS) levels. (A) and (B) After treatment with sTRAIL:FeSOD $(1,000 \mathrm{ng} / \mathrm{ml})$, sTRAlL:mFeSOD $(1,000 \mathrm{ng} / \mathrm{ml})$ or FeSOD $(500 \mathrm{ng} / \mathrm{ml})$ for 3 hours, dihydroethidium (DHE) or dichlorodihydrofluorescein diacetate (DCFDA) was added for detection. (C) through (J) After cells were treated with sTRAIL:FeSOD (1,000 ng/ml) or sTRAIL:mFeSOD $(1,000 \mathrm{ng} / \mathrm{ml})$ for $0,1,2,3,4,5$ or 6 hours, intracellular $\mathrm{H}_{2} \mathrm{O}_{2}, \mathrm{GSH}, \mathrm{O}_{2}{ }^{-}$and ROS were measured by DHR123, NDA, DHE and DCFDA, respectively. The fluorescence was measured by flow cytometry. For each sample, 10,000 events were acquired. Results are expressed as the mean fluorescence intensity. Each bar represents the mean \pm SE obtained from three independent experiments $\left({ }^{*} P<0.05\right.$ vs. untreated control). 


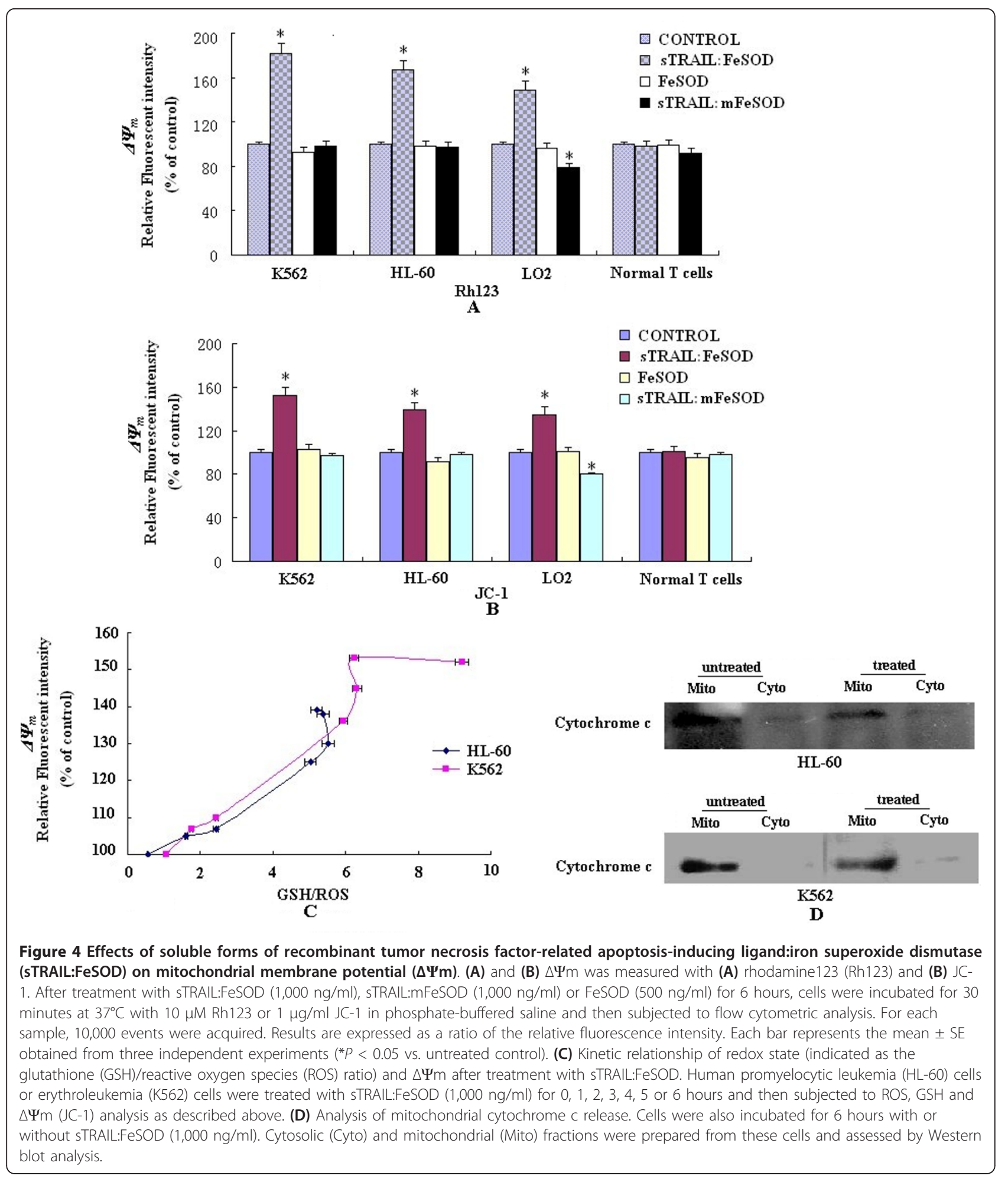

Figure $5 \mathrm{G}$ shows that blocking with DR5 or DR4 antibody partially protected the K562 and HL-60 cells from cell death, whereas the antibody against DR5 had a more pronounced protective effect on STRAIL:FeSODinduced apoptosis than did the antibody against DR4.
No significant apoptosis was noted when blocking with both anti-TRAIL receptor antibodies. These results indicate that the sTRAIL:FeSOD-induced death signaling in the two cell lines depends on DR5 and DR4. After blocking with antibodies against DR5 and/or DR4, the 


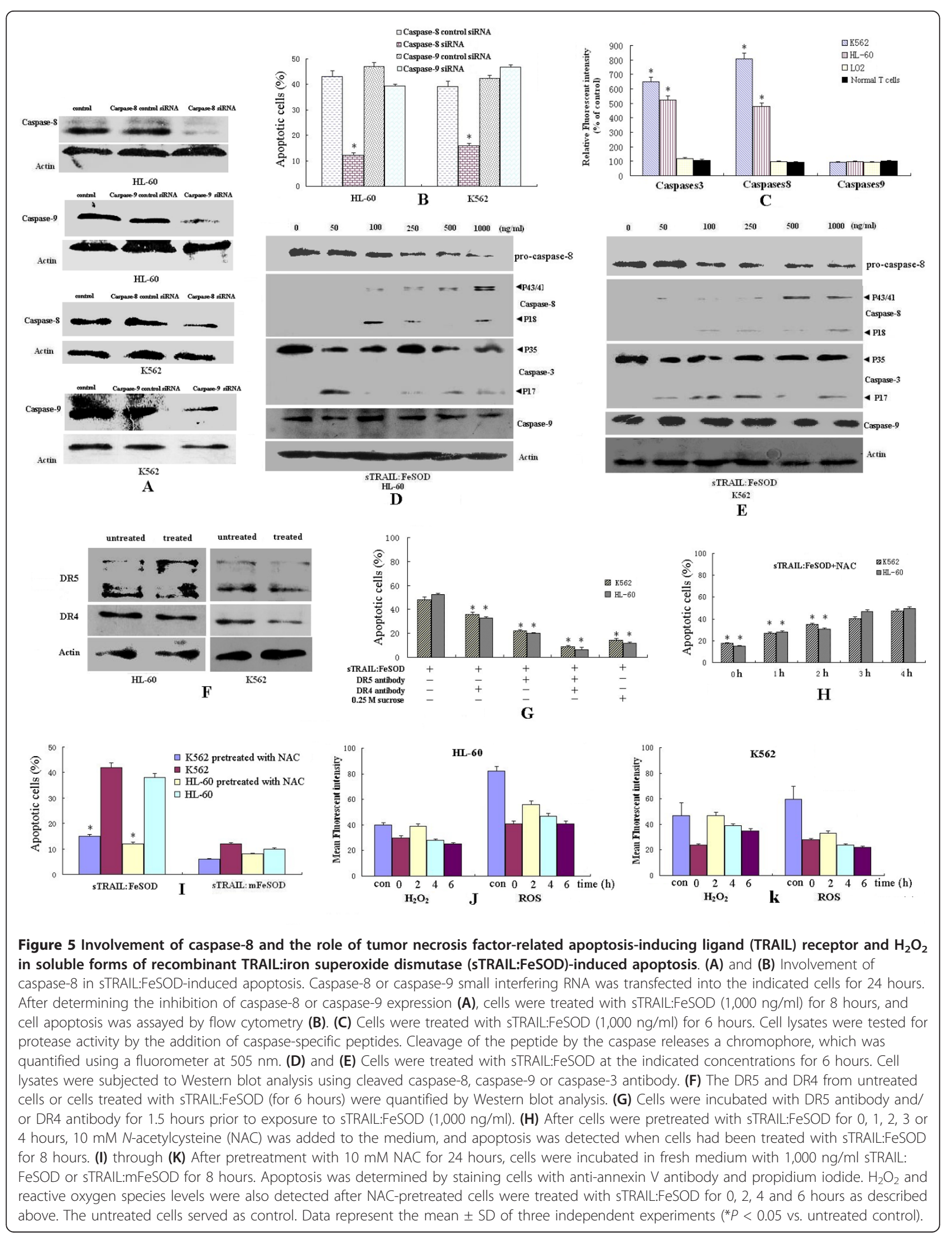


internalization of the fusion protein mirrored the apoptosis results, showing death receptor dependence. There was minimal uptake of sTRAIL:FeSOD when pretreated with both anti-TRAIL receptor antibodies (data not shown), demonstrating the endocytosis to be receptormediated.

To provide evidence for the synergistic effect of sTRAIL and FeSOD, K562 and HL-60 cells were treated in hypertonic medium containing sTRAIL:FeSOD, conditions under which internalization of FeSOD was inhibited. Figure 5G shows that the sTRAIL:FeSOD-induced apoptosis drastically declined in the hypertonic medium, demonstrating FeSOD to be indispensable for sTRAIL: FeSOD-induced apoptosis. The confirmed internalization of sTRAIL:mFeSOD into K562 and HL-60 cells (Figure 2G) and the indistinguishable cell death in the two cell lines after treatment with sTRAIL:mFeSOD (Figures 1D and 1E) further prove the necessity for FeSOD to be internalized to allow for sTRAIL:FeSODinduced apoptosis.

\section{A brief accumulation of $\mathrm{H}_{2} \mathrm{O}_{2}$ is involved in STRAIL: FeSOD-induced apoptosis}

We observed that the elevated $\mathrm{H}_{2} \mathrm{O}_{2}$ levels lasted about 2 hours in K562 and HL-60 cells after treatment with sTRAIL:FeSOD (Figures $3 \mathrm{C}$ and 3D). $\mathrm{H}_{2} \mathrm{O}_{2}$ has been reported to have a direct effect on caspase- 8 activation, and therefore we investigated whether $\mathrm{H}_{2} \mathrm{O}_{2}$ was involved in sTRAIL:FeSOD-induced apoptosis. To that end, cells were treated with sTRAIL:FeSOD in the presence or absence of $\mathrm{N}$-acetylcysteine (NAC) [30]. After pretreatment with sTRAIL:FeSOD for 0,1 or 2 hours, the addition of NAC partially reduced sTRAIL:FeSODinduced apoptosis (Figure $5 \mathrm{H}$ ). When the cells were pretreated with sTRAIL:FeSOD for more than 3 hours, NAC did not show any significant inhibitory effect on sTRAIL:FeSOD-induced cell death. Thus, the results indicate that the production of $\mathrm{H}_{2} \mathrm{O}_{2}$ during $\mathrm{O}_{2}{ }^{-}$scavenging contributed to sTRAIL:FeSOD-induced apoptosis and that caspase- 8 activation by $\mathrm{H}_{2} \mathrm{O}_{2}$ occur within the first 2 hours after sTRAIL:FeSOD treatment. To further assess the role of $\mathrm{H}_{2} \mathrm{O}_{2}$ produced during $\mathrm{O}_{2}{ }^{-}$scavenging in sTRAIL:FeSOD-induced apoptosis, we examined the apoptosis induced by sTRAIL:FeSOD after eliminating intracellular $\mathrm{O}_{2}{ }^{-}$by pretreating HL-60 and $\mathrm{K} 562$ cells with NAC for 24 hours (Figures $5 \mathrm{I}$ to $5 \mathrm{~K}$ ). Because of the prescavenging of $\mathrm{O}_{2}{ }^{-}$, there was little substrate for FeSOD, which caused the $\mathrm{H}_{2} \mathrm{O}_{2}$ to remain at a very low level during the treatment with sTRAIL:FeSOD. Figure 5I shows that cell death was reduced. These data suggest that $\mathrm{H}_{2} \mathrm{O}_{2}$ plays an important role in STRAIL:FeSODinduced apoptosis.

\section{Downregulation of p-Akt and C-FLIP $L$ promotes TRAIL- induced apoptosis in HL-60 and K562 cells}

It is known that p-Akt can be activated by ROS and that elevated Akt activity protects cells against TRAILinduced apoptosis. Figure $5 \mathrm{H}$ shows that decreased $\mathrm{H}_{2} \mathrm{O}_{2}$ levels did not entirely inhibit sTRAIL:FeSODinduced apoptosis. Thus, we postulated that Akt may also be involved in sTRAIL:FeSOD-induced apoptosis in K562 and HL-60 cells. p-Akt was rapidly dephosphorylated within 30 minutes of adding sTRAIL:FeSOD without changing the Akt protein level, and sTRAIL:FeSOD treatment markedly depressed the c-FLIP $\mathrm{L}_{\mathrm{L}}$ level in the two leukemia cell lines (Figures 6A and 6B). c-FLIP was not detected in the HL-60 cells (Figure 6A). c-FLIP was detected in $\mathrm{K} 562$ cells, but did not show any change in expression levels after sTRAIL:FeSOD addition (Figure $6 \mathrm{~B}$ ). Therefore, we hypothesize that $\mathrm{c}-\mathrm{FLIP}_{\mathrm{L}}$ is involved in sTRAIL:FeSOD-induced apoptosis. sTRAIL: FeSOD-induced apoptosis in K562 and HL-60 cells was partially inhibited by c-FLIP $\mathrm{L}_{\mathrm{L}}$ overexpression (Figures 7A to $7 \mathrm{C}$ ), demonstrating that the $\mathrm{p}-\mathrm{Akt} / \mathrm{c}-\mathrm{FLIP}_{\mathrm{L}}$ signaling pathway is also involved in sTRAIL:FeSOD-induced apoptosis. The effect of sTRAIL:FeSOD on the downregulation of c-FLIP ${ }_{L}$ was also determined in cells in which total caspases were blocked (Figure 6E), further proving that cFLIP $_{\mathrm{L}}$ levels were modulated by Akt. Bcl- 2 family proteins are important pro- and antiapoptotic proteins in the cells, but we were unable to detect any changes in $\mathrm{Bcl}-2, \mathrm{Bcl}-\mathrm{X}_{\mathrm{L}}$ and Bax levels or Bid cleavage after 6 hours of sTRAIL: FeSOD treatment.

\section{Low levels of $\mathrm{H}_{2} \mathrm{O}_{2}$ protect LO2 cells from sTRAIL:FeSOD- induced apoptosis}

The downregulation of p-Akt and c-FLIP $\mathrm{L}_{\mathrm{L}}$ was also observed in LO2 cells (Figure 6C), but not in normal $\mathrm{T}$ cells (data not shown). It was not immediately apparent why TRAIL sensitivity did not occur in LO2 cells. LO2 cells are type II, and TRAIL-induced apoptosis can be blocked by caspase- 9 inhibition in these cells (Figure 7D). The results presented in Figure $3 \mathrm{I}$ and Figures $4 \mathrm{~A}$ and $4 \mathrm{~B}$ also suggest that sTRAIL-induced apoptosis in LO2 cells was dependent on mitochondria. Caspase- 9 activity was low, and mitochondria remained polarized after treatment with sTRAIL:FeSOD, which inhibits the mitochondrial apoptotic pathway. Therefore, we hypothesized that the low levels of $\mathrm{H}_{2} \mathrm{O}_{2}$ prevented sTRAIL:FeSOD from converting LO2 into type I cells, which are characterized by high caspase- 8 activity. To test this hypothesis, RNA interference transfection was performed to depress catalase expression in the $\mathrm{LO} 2$ cells, and the $\mathrm{H}_{2} \mathrm{O}_{2}$ levels were found to be much higher than those in the control group after treatment with sTRAIL:FeSOD (Figure 7E). 


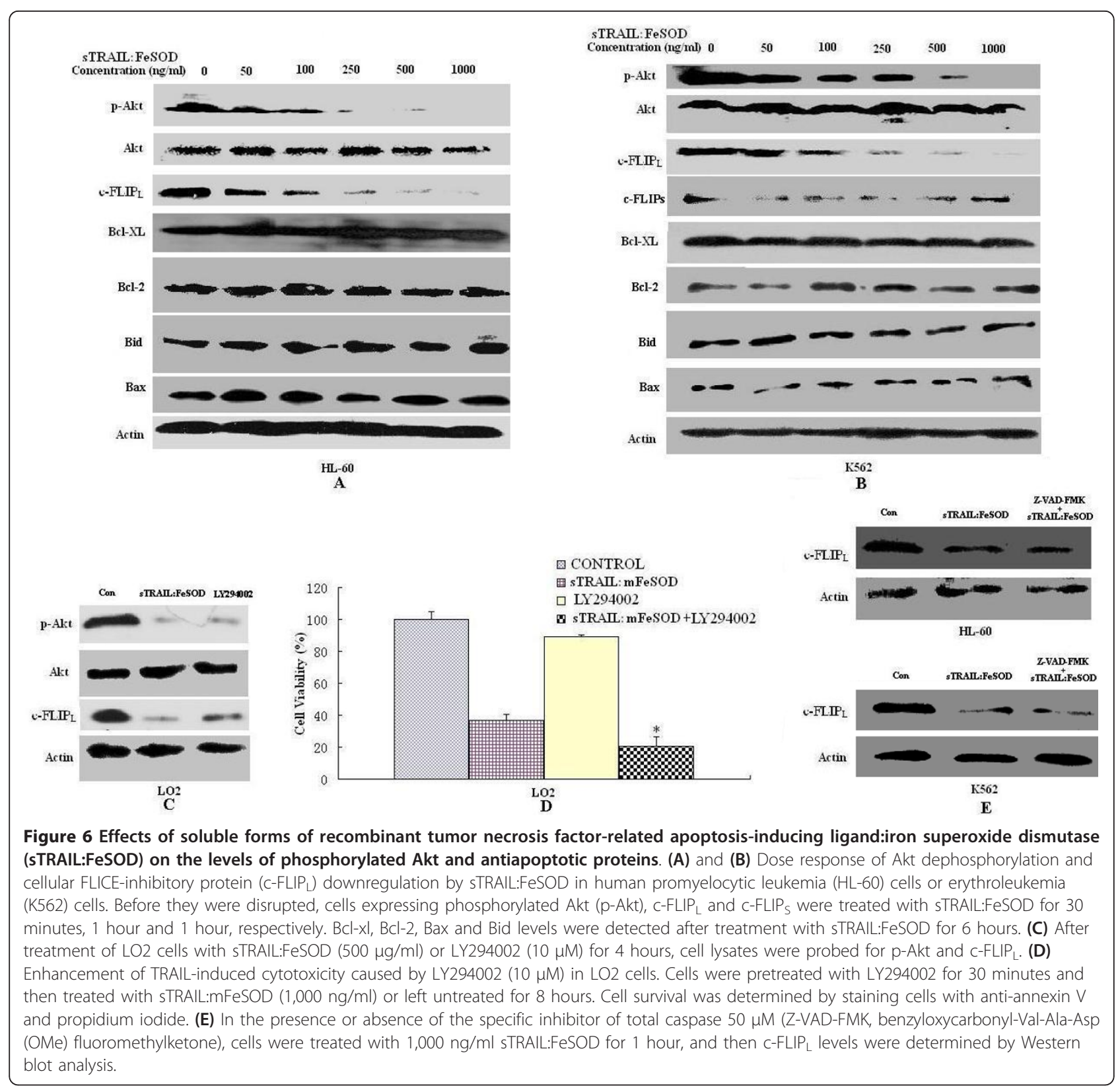

High caspase- 8 activity and apoptosis were induced by sTRAIL:FeSOD (Figures 7F and 7G) in the catalase-deficient $\mathrm{LO} 2$ cells. On the basis of these experimental data, LO2 cells are not converted into type I cells after treatment with sTRAIL:FeSOD. On the contrary, sTRAIL: FeSOD not only depressed caspase- 9 activity but also maintained caspase- 8 activity below a critical threshold because of the low $\mathrm{H}_{2} \mathrm{O}_{2}$ levels, rendering the $\mathrm{LO} 2$ cells insensitive to sTRAIL:FeSOD-induced apoptosis. Thus, without the accumulation of $\mathrm{H}_{2} \mathrm{O}_{2}$, downregulation of $\mathrm{p}$ Akt and c-FLIP $\mathrm{L}_{\mathrm{L}}$ was insufficient to activate enough caspase- 8 to sensitize LO2 to TRAIL-induced apoptosis at a low level of oxidative stress.

\section{Discussion}

Here we describe a novel therapeutic approach for treating cancer using the new cell-permeable fusion protein sTRAIL:FeSOD. The effects of sTRAIL and sTRAIL: FeSOD on apoptosis in LO2 cells in hyperosmotic medium did not show significant differences, suggesting that the FeSOD domain does not change the oligomerization state of sTRAIL (Figures 1B and 1C). When engaging the TRAIL receptors (TRAIL-R1 and TRAIL-R2), the trimeric sTRAIL:FeSOD triggered the TRAIL-induced apoptotic signaling pathway and simultaneously permeated the cell membrane via the receptor-mediated endocytic pathway. Movement throughout the cytoplasm 


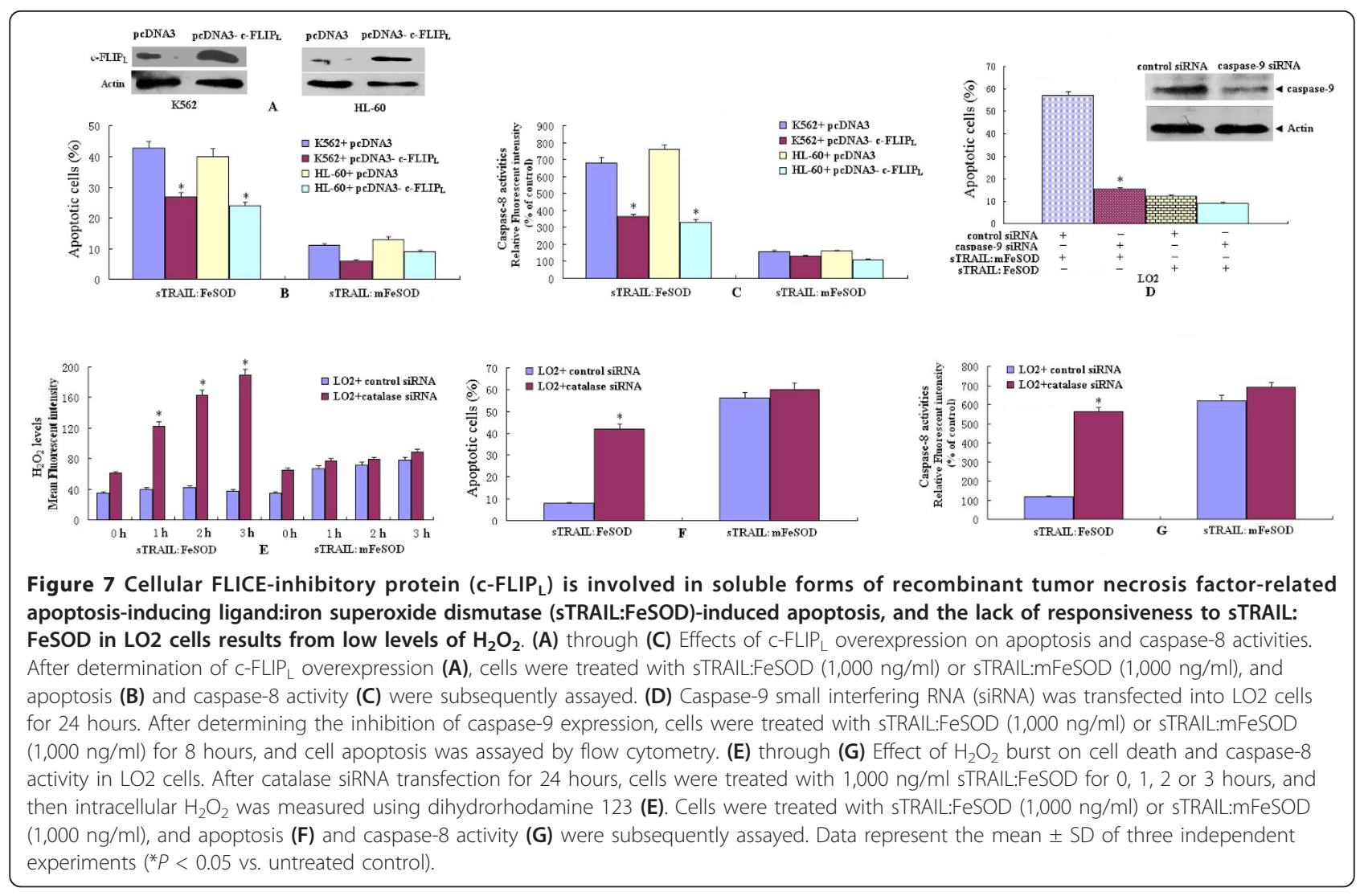

provided FeSOD with the opportunity to scavenge $\mathrm{O}_{2}{ }^{-}$ originating from the mitochondria. Once sTRAIL: FeSOD engaged the TRAIL receptors, TRAIL-induced apoptosis signaling was triggered, seemingly prior to the elimination of intracellular $\mathrm{O}_{2}{ }^{-}$. However, in the current study, the brief accumulation of $\mathrm{H}_{2} \mathrm{O}_{2}$ and the downregulation of p-Akt occurred rapidly enough to enhance the sensitivity of K562 and HL-60 cancer cells to TRAIL-induced apoptosis. The internalization of STRAIL:FeSOD was rapid (Figure 2) and triggered TRAIL-induced apoptosis signaling and the elimination of intracellular $\mathrm{O}_{2}^{-}$to occur nearly simultaneously. In addition, it has been suggested that Fas-associated protein with death domain and caspase- 8 are not recruited soon enough because of the long delay in deathinducing signaling complex assembly in type II cells [31]. Thus, FeSOD had sufficient time to scavenge intracellular $\mathrm{O}_{2}{ }^{-}$and then influence the course of TRAILinduced apoptosis.

The inhibition of $\mathrm{H}_{2} \mathrm{O}_{2}$ accumulation or the overexpression of c-FLIP ${ }_{\mathrm{L}}$ partially suppressed sTRAIL:FeSODinduced apoptosis, and thus we infer that $\mathrm{H}_{2} \mathrm{O}_{2}$ and p-Akt affect caspase- 8 activity via different pathways. Constitutive phosphoinositide 3-kinase (PI3K)/Akt activity has been demonstrated to be one of the most effective antiapoptotic survival pathways in TRAIL-resistant cells, and therefore decreasing p-Akt levels is an important mechanism of averting TRAIL resistance. Tumor cells containing an activating somatic mutation in PI3K are relatively resistant to TRAIL-induced apoptosis [32,33]. After treatment with sTRAIL:FeSOD, p-Akt was downregulated in three cell lines (Figures 6A to 6C), depressing c-FLIP $_{\mathrm{L}}$ expression [20]. However, the LO2 cells responded little to the fusion protein, in contrast to the synergistic apoptosis in TRAIL-resistant K562 and HL-60 cells [26]. The downregulation of Akt activity by LY294002 promoted TRAIL cytotoxicity in LO2 cells (Figure 6D), implying that low oxidative stress induced by FeSOD inhibited TRAIL-induced apoptosis in the LO2 cells. The results of the present study suggest that differences in caspase- 8 activity determine the different cellular effects of sTRAIL:FeSOD on the indicated cells based on the interruption of the mitochondrial apoptotic pathway (Figures $4 \mathrm{~A}, \mathrm{~B}$ and $5 \mathrm{~B}$ to $5 \mathrm{E}$ ). ROS have been reported to regulate caspase activation in TRAILresistant human colon carcinoma cells [17]. Perez-Cruz et al. [34] indicated that intracellular vitamin $C$ can quench some of these ROS, reducing caspase- 8 activation, similar to what we observed in the $\mathrm{LO} 2$ cells. However, Fas et al. [10] found that wogonin sensitizes resistant malignant cells to TRAIL by shifting levels of the TRAIL-induced free radical $\mathrm{O}_{2}{ }^{-}$, consistent with our 
results demonstrating the sensitization of K562 and HL-60 cells.

ROS levels have been found to be significantly higher in cancer cells than in normal cells, and the activity of antioxidant enzymes such as glutathione peroxidase, catalase and SOD has been shown to be significantly lower in cancer patients than in controls [35]. The higher ROS levels and lower antioxidant enzyme activities (Figures $3 \mathrm{C}$ to $3 \mathrm{~F}$ ) make the transient burst of $\mathrm{H}_{2} \mathrm{O}_{2}$ possible in $\mathrm{K} 562$ and HL-60 cells; however, because of the lower ROS levels and vigorous antioxidant system, the brief accumulation of $\mathrm{H}_{2} \mathrm{O}_{2}$ was not detected in LO2 cells (Figures $3 \mathrm{G}$ and $3 \mathrm{I}$ ). The brief accumulation of $\mathrm{H}_{2} \mathrm{O}_{2}$ during $\mathrm{O}_{2}{ }^{-}$scavenging was involved in the sTRAIL:FeSOD-induced apoptosis in K562 and HL-60 cells (Figures 5H to 5K), possibly exerting a direct effect on caspase-8 activation [36]. The low $\mathrm{H}_{2} \mathrm{O}_{2}$ levels protected LO2 cells from sTRAIL:FeSODinduced apoptosis (Figures 7E to 7G). Normal T cells produced very little ROS, and therefore only a small shift in redox state was seen, which may explain why sTRAIL: FeSOD did not sensitize normal T cells to undergo apoptosis. Our studies reveal that sTRAIL:FeSOD reduces the level of intracellular $\mathrm{O}_{2}^{-}$, with two results: the downregulation of p-Akt arising from a low level of $\mathrm{O}_{2}{ }^{-}$and the transitory accumulation of $\mathrm{H}_{2} \mathrm{O}_{2}$, both of which may increase the amount of available active caspase- 8 [37]. However, a low level of $\mathrm{O}_{2}{ }^{-}$, impairing caspase-8 activation [36], and stable mitochondria may inhibit apoptosis. Thus, we infer that the relative ratio of these opposing effects described above determines the sensitivity of a cell to sTRAIL: FeSOD and that this relative ratio may be associated with the cell type and the level of $\mathrm{O}_{2}^{-}$. Without the accumulation of $\mathrm{H}_{2} \mathrm{O}_{2}$, the available activated caspase- 8 was insufficient (Figures $5 \mathrm{C}$ and $7 \mathrm{E}$ to $7 \mathrm{G}$ ). At the same time, caspase-9 activity was inhibited (Figures 4 and 5C), which means that the mitochondrial apoptotic pathway was interrupted. Thus, sTRAIL:FeSOD cannot sensitize LO2 cells to apoptosis when there is insufficient activated caspase- 8 to excite the downstream apoptotic pathway in the absence of the intrinsic apoptotic pathway. The induction of apoptosis in K562 and HL-60 cells implies that the net result of intracellular $\mathrm{O}_{2}{ }^{-}$scavenging by sTRAIL:FeSOD is the presence of a critical amount of activated caspase-8. Thus, in environments of low-level oxidative stress, the cellular context may influence the relative ratio of the opposing effects and subsequently determine whether this low level of oxidative stress favors apoptosis or survival.

Because of the effective protection against the mitochondrial apoptotic pathway mediated by the increased expression of Bcl- $\mathrm{X}_{\mathrm{L}}$ and the mutation of caspase- 8 , K562 and HL-60 cells exhibit strong resistance to chemotherapeutic agents [38,39]. However, after treatment with sTRAIL:FeSOD, K562 and HL-60 cells undergoing apoptosis retained their $\Delta \Psi \mathrm{m}$ (Figure 4), and we also failed to detect a difference in the expression level of $\mathrm{Bcl}-2$, Bax, Bid or Bcl- $\mathrm{X}_{\mathrm{L}}$ (Figures $6 \mathrm{~A}$ and $6 \mathrm{~B}$ ) or a change in the distribution of cytochrome $c$ (Figure 4D). The unchanged pattern of cytochrome $c$ localization may be associated with a decrease in ROS levels, leading to mitochondrial stability. Depressed caspase-9 expression did not suppress apoptosis, demonstrating that sTRAIL:FeSOD-induced apoptosis was independent of the mitochondrial apoptotic pathway in K562 and HL60 cells (Figures 5A and 5B). Mohr et al. [40] indicated that high levels of MnSOD protect colorectal cancer cells from TRAIL-induced apoptosis by inhibition of Smac/DIABLO release. However, this effect may be limited to type II cells, in which death receptor-mediated apoptosis is dependent on mitochondria. In contrast, in the present study, treatment with sTRAIL:FeSOD caused K562 and HL-60 cells to convert to type I cells and to apoptose independently of the intrinsic apoptotic pathway, consistent with the effects of erythroid differentiation [41]. Thus, mitochondrial hyperpolarization does not delay apoptosis when a critical amount of caspase-8 has been activated, which may be the mechanism that regulates type I cell apoptosis independently of the mitochondrial signaling pathway [36].

Death receptors are expressed in liver tissue as well as in isolated hepatocytes [5], and for this reason sTRAIL: FeSOD was able to permeate the cell membrane and reduce the oxidative stress in $\mathrm{LO} 2$ cells without causing cytotoxicity. Maintaining the balance of opposing effects is important when treating normal cells with sTRAIL: FeSOD, because an appropriate ROS level is extremely important for preserving vital cellular and biochemical functions. Our future work will focus on the task of estimating intracellular ROS production in an individual cell to determine a treatment dose that maintains ROS levels at an appropriate interval, killing cancer cells without inducing normal cell death. In light of the different sensitivities of different cell types to ROS and the hypersensitivity of tumor cells to decreased levels of ROS relative to normal cells, the ability to control TRAIL cytotoxicity through the regulation of intracellular ROS levels will be a breakthrough in the utilization of TRAIL. Undoubtedly, sTRAIL:FeSOD is a good potential therapeutic choice.

\section{Conclusions}

In conclusion, our research has shown that a cellpermeable fusion protein, sTRAIL:FeSOD, selectively sensitized K562 and HL-60 cancer cells to TRAILinduced apoptosis but did not sensitize normal human hepatocytes (LO2 cells) or T cells. sTRAIL:FeSOD is a potent antioxidant that produces $\mathrm{H}_{2} \mathrm{O}_{2}$ during intracellular $\mathrm{O}_{2}{ }^{-}$scavenging and downregulates $\mathrm{p}$-Akt and c-FLIP ${ }_{L}$. Thus, sTRAIL:FeSOD enhances TRAIL-induced 
apoptosis in leukemia cells and, at the same time, avoids the negative effects of high levels of ROS. After treatment with sTRAIL:FeSOD, the mitochondria were still intact, and the TRAIL-resistant K562 and HL-60 cells successfully converted into type I cells. In addition, the downregulation of c-FLIP $\mathrm{L}_{\mathrm{L}}$ was not sufficient to sensitize LO2 to TRAIL-induced apoptosis without $\mathrm{H}_{2} \mathrm{O}_{2}$ accumulation. These data suggest that sTRAIL:FeSOD can serve as a promising pharmaceutical agent for the treatment of leukemia.

\section{Methods}

\section{Reagents and antibodies}

The fluorescent probes DHE, Rh123 and the peroxidesensitive fluorophore DCFDA were purchased from Molecular Probes (Eugene, Oregon, USA). The total caspase inhibitor Z-VAD-FMK (benzyloxycarbonyl-ValAla-Asp (OMe) fluoromethylketone) and the Annexin V-FITC Apoptosis Detection Kit were obtained from Merck (Darmstadt, Germany). Caspase-9, caspase-3 and caspase- 8 fluorometric assay kits were obtained from BioVision (Palo Alto, California, USA). Rabbit p-Akt (Thr308) antibody; mouse Akt antibody; rabbit c-FLIP and c-FLIP ${ }_{\mathrm{L}}$ antibodies; Bcl- $\mathrm{X}_{\mathrm{L}}, \mathrm{Bcl}-2$, Bax and Bid antibodies; caspase- 9 , caspase- 3 and caspase- 8 antibodies; and horseradish peroxidase (HRP)-conjugated goat antirabbit antibody were purchased from Cell Signaling Technology (Boston, Massachusetts, USA), along with LY294002 (PI3K inhibitor). TRAIL, DR4 and DR5 antibodies and donkey antimouse immunoglobulin G-HRP were obtained from Santa Cruz Biotechnology (Santa Cruz, CA, USA). All of the remaining reagents were purchased from Sigma (Saint Louis, Missouri, USA).

\section{Cell lines and culture conditions}

The pUCm-T-TRAIL vector was kindly provided by Pro Liu (Institute of Biochemistry and Cell Biology, Shanghai Institute for Biological Science, Chinese Academy of Science (Shanghai, China). Escherichia coli DH5 $\alpha$ [supE4 $\Delta l a c \mathrm{U} 169$ (80lacZDM15) hsdR17 recA1 endA1 gyrA96 thi-1 relA1], E. coli BL21 (DE3) (hsdS gal ( $\lambda$ cIts857 ind1 Sam7 nin5 lacUV5-T7 gene 1)), pET-28a(+) vector, pUCm-T vector and pET22-FeSOD vector were available at our institute. E. coli DH5 $\alpha$ and E. coli BL21 (DE3) were maintained at $37^{\circ} \mathrm{C}$ in Luria-Bertani (LB) medium supplemented with the appropriate antibiotics. K562, HL-60 and LO2 cells were available in our laboratory and cultured in a humidified $5 \% \mathrm{CO}_{2}$ atmosphere at $37^{\circ} \mathrm{C}$ in RPMI 1640 medium supplemented with $10 \%$ fetal calf serum and antibiotics (penicillin and streptomycin). Human peripheral $\mathrm{T}$ cells were prepared as described previously [42]. T cells were activated with $1 \mu \mathrm{g} / \mathrm{ml}$ polyhydroxyalkanoate for 20 hours, washed three times and then cultured for an additional 5 days in the presence of
$25 \mathrm{U} / \mathrm{ml}$ interleukin 2. Transfections of K562, HL-60 and LO2 cells were performed with the expression vectors pcDNA3-c-FLIP ${ }_{L}$, caspase-8 and caspase-9 small interfering RNA (siRNA), catalase siRNA or control siRNA (Santa Cruz Biotechnology) using the Attractene transfection reagent (Qiagen, Hilden, Germany).

\section{Production, purification and immunoblot analyses of sTRAIL and sTRAIL:FeSOD}

A DNA fragment encoding the extracellular domain of human TRAIL (sTRAIL; 114 to 281 aa) was amplified from the pUCm-T-TRAIL vector with the primers sTRAIL-NcoI (5'-CATGCCATGGTGAGAGAAAGA GGTCCTCAGAGAGTAG-3') and sTRAIL-SalI (5'ACGCGTCGACTCCGCCTCCACCGCCAACTAAAA AGGCC-3') and directionally inserted into pET28a(+) plasmid to form pET28-sTRAIL using the unique NcoI and SalI restriction enzyme sites. The FeSOD fragment was amplified from the pET22-FeSOD vector, polymerase chain reaction-amplified with FeSOD-SalI (5'-ACGCGTCGACTCATTTGTACAGCTCCCACTACCCT-3') and FeSOD-NotI (5'-ATAAGAATGCGGCCGCAGCTTTGG CCAAGTTTTC-3') primers and cloned in frame with the unique SalI and NotI restriction enzymes, yielding plasmid pET28-sTRAIL:FeSOD. Nucleotide sequences of the insert regions within these constructs were independently verified by automated DNA sequencing.

E. coli BL-21 DE3 (pLys) were transformed with pET28-sTRAIL and then induced in the presence of $0.8 \mathrm{mM}$ IPTG in 1 liter of LB culture medium at $27^{\circ} \mathrm{C}$ for 3 hours [43]. Bacterial pellets were then collected by centrifugation at 5,000 rpm for 5 minutes and washed twice with ice-cold PBS. Pellets were sonicated and lysed in Triton X-100 lysis buffer $(10 \mathrm{mM}$ TrisHCl, $\mathrm{pH}$ 7.6, $150 \mathrm{mM} \mathrm{NaCl}, 10 \%$ glycerol, $1 \%$ Triton X-100, $0.1 \mathrm{mM}$ dithiothreitol (DTT), $0.1 \mathrm{mM}$ phenylmethanesulfonylfluoride) for 30 minutes on ice. The lysis supernatant was then cleared by centrifugation and poured onto a column with $5 \mathrm{ml}$ of nickel-nitrilotriacetic acid Superflow resin (Qiagen), and the packed resin was washed with buffer consisting of imidazole gradient concentrations (0 to $500 \mathrm{mM}$ ). The sTRAIL:FeSOD fusion protein was expressed at $37^{\circ} \mathrm{C}$ and lysed from pET28STRAIL:FeSOD as described above. The achieved sedimentation (sTRAIL:FeSOD fusion protein) was then dissolved in lysis buffer $(10 \mathrm{mM}$ Tris $\mathrm{HCl}, \mathrm{pH}$ 7.6, $150 \mathrm{mM} \mathrm{NaCl}, 8 \mathrm{M}$ urea) overnight. The lysate was purified as described above. After purification, the denatured protein was renatured in buffer $(10 \mathrm{mM}$ Tris $\mathrm{HCl}$, $\mathrm{pH}$ 7.6, $150 \mathrm{mM} \mathrm{NaCl}, 0.5 \mathrm{M} \mathrm{L}$-arginine, $0.5 \mathrm{mM} \mathrm{GSH}$, $0.5 \mathrm{mM}$ L-Glutathione oxidized, $10 \%$ glycerol, $10 \mu \mathrm{M}$ $\mathrm{Fe}^{3+}, 10 \mu \mathrm{M} \mathrm{Zn^{2+ }}$ ) consisting of a gradient of urea concentrations $(0$ to $8 \mathrm{M})$ at $10^{\circ} \mathrm{C}$. The renatured proteins were collected and flowed over a Sephadex G-100 
column for gel filtration chromatography. By disordering the amino acid sequence in the conserved region (69 to 84 aa, 120 to 132 aa and 162 to 169 aa) of FeSOD, we also produced a mutant form of fused protein (sTRAIL: $\mathrm{mFeSOD}$ ) that was deficient in its enzymatic activity. The expression of sTRAIL, sTRAIL:FeSOD and sTRAIL: mFeSOD was assessed by Western blot analysis. The TRAIL-induced apoptosis activity of sTRAIL, sTRAIL: FeSOD and sTRAIL:mFeSOD was assayed by treating the TRAIL-sensitive LO2 cells in hypertonic medium containing sucrose $(0.25 \mathrm{M})$, conditions that inhibited the endocytosis of TRAIL, eliminating the effect of FeSOD [25]. The SOD activity of purified sTRAIL: FeSOD was determined using the xanthine/xanthine oxidase system. sTRAIL:mFeSOD was used as control to analyze the cellular effects of sTRAIL:FeSOD.

\section{Apoptosis assay}

To identify early apoptotic changes, cells were seeded in six-well plates $\left(5 \times 10^{5}\right.$ cells/well $)$ and incubated for 8 hours in the presence of FeSOD, sTRAIL, sTRAIL: FeSOD or sTRAIL:mFeSOD. Cells were collected at $1,000 \mathrm{rpm}$ for 5 minutes at $4^{\circ} \mathrm{C}$. After being washed, the cells were then stained with fluorescein isothiocyanate (FITC)-conjugated anti-annexin V antibody and PI, followed by flow cytometric analysis (Becton Dickinson, Franklin Lakes, New Jersey, USA). The results are presented as the percentage of apoptosis. For each sample, 10,000 events were acquired in each group. Experiments were performed three separate times for each cell line.

\section{Preparation of FITC-labeled sTRAIL:FeSOD conjugate}

By labeling with FITC, we could trace the permeation process of sTRAIL:FeSOD through the cell membrane. STRAIL:FeSOD (10 mg) was dissolved in $5 \mathrm{ml}$ of $500 \mathrm{mM}$ carbonate buffer ( $\mathrm{pH}$ 8.5) without sodium azide. Ten milligrams of FITC were dissolved in $1 \mathrm{ml}$ of anhydrous dimethyl sulfoxide immediately before use, and then $50 \mu$ l of FITC were added to the dissolved sample. The tube was wrapped in foil and then incubated and rotated at room temperature for 2 hours. The labeled sTRAIL:FeSOD was desalted with a Sephadex G-25 column to remove unreacted FITC. The fluorescence intensity of sample was measured by using a fluorescence spectrophotometer. FeSOD and sTRAIL: $\mathrm{mFeSOD}$ were treated as described above. No difference was observed in the efficiency of FITC-labeled sTRAIL: FeSOD compared with unlabeled protein in terms of inducing apoptosis in LO2 cells (data not shown).

\section{Determination of sTRAIL:FeSOD internalization by confocal microscopy and flow cytometry}

Prepared K562 cells were washed extensively with PBS and incubated in RPMI 1640 medium containing 5 rg/ ml FITC-conjugated sTRAIL:FeSOD for 5, 15 or 30 minutes at $37^{\circ} \mathrm{C}$. After internalization, following three washes with PBS to remove unbound protein and an acid wash $(0.2 \mathrm{M} \mathrm{NaCl}, 0.2 \mathrm{M}$ acetic acid) to strip the surface-associated ligand, intracellular FITC was observed by LSCM (LSM510; Carl Zeiss, Jene, Germany), and quantitative data were analyzed by using flow cytometry. LO2 cells were incubated in RPMI 1640 medium containing hyperosmotic sucrose $(0.25 \mathrm{M})$ [44] and $5 \mu \mathrm{g} / \mathrm{ml}$ FITC-conjugated sTRAIL:FeSOD and then counterstained with the DNA dye Hoechst 33342 (Sigma).

\section{Cellular oxidative stress assay by flow cytometry}

After incubation with $1000 \mathrm{ng} / \mathrm{ml}$ sTRAIL:FeSOD in fresh culture medium for the indicated amount of time, cells were washed and incubated with $20 \mu \mathrm{M}$ dihydrorhodamine 123 (DHR123) (for $\mathrm{H}_{2} \mathrm{O}_{2}$ ), $50 \mu \mathrm{M}$ 2,3Naphthalenedicarboxaldehyde (NDA) (for GSH), $20 \mu \mathrm{M}$ DHE (for $\mathrm{O}_{2}^{-}$) or $5 \mu \mathrm{M}$ DCFDA (for total ROS) at $37^{\circ} \mathrm{C}$ for 30 minutes. The cells were then washed three times with probe-free phosphate buffer. The fluorescence intensity was measured by flow cytometry.

\section{Measurement of mitochondrial membrane potential}

Cells were precultured in a 24 -well plate at a concentration of $0.5 \times 10^{6}$ cells/well. Subsequently, cells were treated with $1,000 \mathrm{ng} / \mathrm{ml}$ sTRAIL:FeSOD, $500 \mathrm{ng} / \mathrm{ml}$ rTRAIL or $500 \mathrm{ng} / \mathrm{ml}$ FeSOD for 6 hours or were left untreated as controls. After treatment with sTRAIL: FeSOD, cells were harvested and washed with prewarmed PBS. The cells were then incubated with $10 \mu \mathrm{M}$ $\mathrm{Rh} 123$ or $1 \mu \mathrm{g} / \mathrm{ml} \mathrm{JC}-1$ at $37^{\circ} \mathrm{C}$ for 30 minutes, washed and subsequently analyzed by flow cytometry.

\section{Caspase activity assay}

Prepared cells $\left(1 \times 10^{6} / \mathrm{ml}\right)$ were treated for 6 hours with $1,000 \mathrm{ng} / \mathrm{ml}$ sTRAIL:FeSOD, $500 \mathrm{ng} / \mathrm{ml} \mathrm{rTRAIL}$ or $500 \mathrm{ng} / \mathrm{ml}$ FeSOD and then lysed in ice-cold lysis buffer (Biovision) for 10 minutes. After centrifugation for 10 minutes at $15,000 \times g$, cell lysates were tested for protease activity by the addition of reaction buffer (containing $10 \mathrm{mM}$ DTT) and caspase-specific peptides conjugated to the fluorescence AFC (7-amino-4-trifluoromethyl coumarin). Cleavage of the peptide by caspase releases the chromophore, which was quantified using a fluorometer at $505 \mathrm{~nm}$.

\section{Western blot analysis}

Treated cells were collected, washed in PBS and then lysed with lysis buffer on ice. Approximately $20 \mu \mathrm{g}$ of lysed protein were separated by sodium dodecyl sulfatePAGE and transferred to a nitrocellulose blotting membrane, blocked for 1.5 hours in blocking buffer ( $5 \%$ 
bovine serum albumin solution and $0.1 \%$ Tween 20 in Tris-buffered saline (TBST)). After three washes in TBST, membranes were probed with the indicated antibodies in blocking buffer overnight. After three washing steps in TBST, the blots were subjected to appropriate secondary antibodies for 1.5 hours in blocking buffer. After two washes in TBST for 30 minutes, proteins were visualized by chemiluminescence detection.

\section{Acknowledgements}

This work was supported by grant 30900760 from the National Natural Science Foundation of China.

\section{Author details}

'Institute of Biochemistry, Zhejiang University, Hangzhou, 310058, PR China. ${ }^{2}$ Institute of Biochemistry, College of Life Sciences, Zijingang campus, Room 345, Zhejiang University, Hangzhou, PR China.

\section{Authors' contributions}

HYT designed the research, performed the experiments and wrote the paper. YQ analyzed the data and performed part of the experiments. JYL performed part of the experiments. XGG designed the research and revised the paper. All authors read and approved the final manuscript.

Received: 29 January 2011 Accepted: 19 March 2011

Published: 19 March 2011

\section{References}

1. Wiley SR, Schooley K, Smolak PJ, Din WS, Huang CP, Nicholl JK, Sutherland GR, Smith TD, Rauch C, Smith CA, Goodwin RG: Identification and characterization of a new member of the TNF family that induces apoptosis. Immunity 1995, 3:673-682.

2. Wang S: The promise of cancer therapeutics targeting the TNF-related apoptosis-inducing ligand and TRAIL receptor pathway. Oncogene 2008, 27:6207-6215.

3. Ashkenazi A, Pai RC, Fong S, Leung S, Lawrence DA, Marsters SA, Blackie C, Chang L, McMurtrey AE, Hebert A, DeForge L, Koumenis IL, Lewis D, Harris L, Bussiere J, Koeppen H, Shahrokh Z, Schwall RH: Safety and antitumor activity of recombinant soluble Apo2 ligand. J Clin Invest 1999, 104:155-162.

4. Walczak H, Miller RE, Ariail K, Gliniak B, Griffith TS, Kubin M, Chin W, Jones J, Woodward A, Le T, Smith C, Smolak P, Goodwin RG, Rauch CT, Schuh JC, Lynch DH: Tumoricidal activity of tumor necrosis factor-related apoptosis-inducing ligand in vivo. Nat Med 1999, 5:157-163.

5. Jo M, Kim TH, Seol DW, Esplen JE, Dorko K, Billiar TR, Strom SC: Apoptosis induced in normal human hepatocytes by tumor necrosis factor-related apoptosis-inducing ligand. Nat Med 2000, 6:564-567.

6. Leverkus M, Neumann M, Mengling T, Rauch $C T$, Brocker EB, Krammer PH, Walczak H: Regulation of tumor necrosis factor-related apoptosisinducing ligand sensitivity in primary and transformed human keratinocytes. Cancer Res 2000, 60:553-559.

7. Itoh M, Noutomi T, Toyota H, Mizuguchi J: Etoposide-mediated sensitization of squamous cell carcinoma cells to tumor necrosis factorrelated apoptosis-inducing ligand (TRAIL)-induced loss in mitochondrial membrane potential. Oral Oncol 2003, 39:269-276.

8. Dida F, Li Y, Iwao A, Deguchi T, Azuma E, Komada Y: Resistance to TRAILinduced apoptosis caused by constitutional phosphorylation of Akt and PTEN in acute lymphoblastic leukemia cells. Exp Hematol 2008, 36:1343-1353.

9. Zhang $Y$, Zhang B: TRAIL resistance of breast cancer cells is associated with constitutive endocytosis of death receptors 4 and 5 . Mol Cancer Res 2008, 6:1861-1871.

10. Fas SC, Baumann S, Zhu JY, Giaisi M, Treiber MK, Mahlknecht U, Krammer PH, Li-Weber M: Wogonin sensitizes resistant malignant cells to TNFa- and TRAIL-induced apoptosis. Blood 2006, 108:3700-3706.

11. Belyanskaya LL, Marti TM, Hopkins-Donaldson S, Kurtz S, Felley-Bosco E, Stahel RA: Human agonistic TRAIL receptor antibodies Mapatumumab and Lexatumumab induce apoptosis in malignant mesothelioma and act synergistically with cisplatin. Mol Cancer 2007, 6:66.

12. Meurette O, Fontaine A, Rebillard A, Le Moigne G, Lamy T, LagadicGossmann D, Dimanche-Boitrel MT: Cytotoxicity of TRAIL/anticancer drug combinations in human normal cells. Ann N Y Acad Sci 2006, 1090:209-216.

13. Koschny R, Walczak H, Ganten TM: The promise of TRAIL: potential and risks of a novel anticancer therapy. J Mol Med 2007, 85:923-935.

14. Bremer E, Samplonius DF, van Genne L, Dijkstra MH, Kroesen BJ, de Leij LF, Helfrich W: Simultaneous inhibition of epidermal growth factor receptor (EGFR) signaling and enhanced activation of tumor necrosis factorrelated apoptosis-inducing ligand (TRAIL) receptor-mediated apoptosis induction by an scFv:sTRAIL fusion protein with specificity for human EGFR. J Biol Chem 2005, 280:10025-10033.

15. Lowe SW, Ruley HE, Jacks T, Housman DE: p53-dependent apoptosis modulates the cytotoxicity of anticancer agents. Cell 1993, 74:957-967.

16. Kang J, Chen J, Zhang D, Da W, Ou Y: Synergistic killing of human leukemia cells by antioxidants and trichostatin A. Cancer Chemother Pharmacol 2004, 54:537-545.

17. Behrend L, Mohr A, Dick T, Zwacka RM: Manganese superoxide dismutase induces p53-dependent senescence in colorectal cancer cells. Mol Cell Biol 2005, 25:7758-7769.

18. Jubeh TT, Antler S, Haupt S, Barenholz Y, Rubinstein A: Local prevention of oxidative stress in the intestinal epithelium of the rat by adhesive liposomes of superoxide dismutase and tempamine. Mol Pharm 2005, 2:2-11.

19. Lu M, Gong X, Lu Y, Guo J, Wang C, Pan Y: Molecular cloning and functional characterization of a cell-permeable superoxide dismutase targeted to lung adenocarcinoma cells: inhibition cell proliferation through the Akt/p27 ${ }^{\text {kip1 }}$ pathway. J Biol Chem 2006, 281:13620-13627.

20. Panka DJ, Mano T, Suhara T, Walsh K, Mier JW: Phosphatidylinositol 3kinase/Akt activity regulates C-FLIP expression in tumor cells. J Biol Chem 2001, 276:6893-6896

21. Wang X, Chen W, Zeng W, Bai L, Tesfaigzi Y, Belinsky SA, Lin Y: Aktmediated eminent expression of C-FLIP and MCl-1 confers acquired resistance to TRAIL-induced cytotoxicity to lung cancer cells. Mol Cancer Ther 2008, 7:1156-1163.

22. Shrader M, Pino MS, Lashinger L, Bar-Eli M, Adam L, Dinney CP, McConkey DJ: Gefitinib reverses TRAIL resistance in human bladder cancer cell lines via inhibition of AKT-mediated X-linked inhibitor of apoptosis protein expression. Cancer Res 2007, 67:1430-1435.

23. Martin D, Salinas M, Fujita N, Tsuruo T, Cuadrado A: Ceramide and reactive oxygen species generated by $\mathrm{H}_{2} \mathrm{O}_{2}$ induce caspase-3-independent degradation of Akt/protein kinase B. J Biol Chem 2002, 277:42943-42952.

24. Kohlhaas SL, Craxton A, Sun XM, Pinkoski MJ, Cohen GM: Receptormediated endocytosis is not required for tumor necrosis factor-related apoptosis-inducing ligand (TRAIL)-induced apoptosis. J Biol Chem 2007, 282:12831-12841.

25. Li D, Randhawa VK, Patel N, Hayashi M, Klip A: Hyperosmolarity reduces GLUT4 endocytosis and increases its exocytosis from a VAMP2independent pool in L6 muscle cells. J Biol Chem 2001, 276:22883-22891.

26. Griffith TS, Lynch DH: TRAIL: a molecule with multiple receptors and control mechanisms. Curr Opin Immunol 1998, 10:559-563.

27. Lum JJ, Schnepple DJ, Badley AD: Acquired T-cell sensitivity to TRAll mediated killing during HIV infection is regulated by CXCR4-gp120 interactions. AIDS 2005, 19:1125-1133.

28. Kamata $\mathrm{H}$, Hirata $\mathrm{H}$ : Redox regulation of cellular signalling. Cell Signal 1999, 11:1-14

29. Matysiak M, Jurewicz A, Jaskolski D, Selmaj K: TRAIL induces death of human oligodendrocytes isolated from adult brain. Brain 2002, 125:2469-2480.

30. Sundaresan $M, Y u Z X$, Ferrans $V J$, Irani $K$, Finkel T: Requirement for generation of $\mathrm{H}_{2} \mathrm{O}_{2}$ for platelet-derived growth factor signal transduction. Science 1995, 270:296-299.

31. Algeciras-Schimnich A, Pietras EM, Barnhart BC, Legembre P, Vijayan $S$, Holbeck SL, Peter ME: Two CD95 tumor classes with different sensitivities to antitumor drugs. Proc Natl Acad Sci USA 2003, 100:11445-11450.

32. Samuels Y, Diaz LA Jr, Schmidt-Kittler O, Cummins JM, Delong L, Cheong I, Rago C, Huso DL, Lengauer C, Kinzler KW, Vogelstein B, Velculescu VE: Mutant PIK3CA promotes cell growth and invasion of human cancer cells. Cancer Cell 2005, 7:561-573. 
33. Johnstone RW, Frew AJ, Smyth MJ: The TRAIL apoptotic pathway in cancer onset, progression and therapy. Nat Rev Cancer 2008, 8:782-798.

34. Perez-Cruz I, Carcamo JM, Golde DW: Vitamin C inhibits FAS-induced apoptosis in monocytes and U937 cells. Blood 2003, 102:336-343.

35. Mantovani G, Maccio A, Madeddu C, Mura L, Gramignano G, Lusso MR, Massa $E$, Mocci M, Serpe R: Antioxidant agents are effective in inducing lymphocyte progression through cell cycle in advanced cancer patients: assessment of the most important laboratory indexes of cachexia and oxidative stress. J Mol Med 2003, 81:664-673.

36. Perez-Cruz I, Carcamo JM, Golde DW: Caspase-8 dependent TRAIL-induced apoptosis in cancer cell lines is inhibited by vitamin C and catalase. Apoptosis 2007, 12:225-234.

37. Geserick P, Drewniok C, Hupe M, Haas TL, Diessenbacher P, Sprick MR, Schon MP, Henkler F, Gollnick H, Walczak H, Leverkus M: Suppression of CFLIP is sufficient to sensitize human melanoma cells to TRAIL- and CD95L-mediated apoptosis. Oncogene 2008, 27:3211-3220.

38. McGahon A, Bissonnette R, Schmitt M, Cotter KM, Green DR, Cotter TG: $B C R-A B L$ maintains resistance of chronic myelogenous leukemia cells to apoptotic cell death. Blood 1994, 83:1179-1187.

39. Cheng J, Hylander BL, Baer MR, Chen X, Repasky EA: Multiple mechanisms underlie resistance of leukemia cells to Apo2 ligand/TRAIL. Mo/ Cancer Ther 2006, 5:1844-1853.

40. Mohr A, Büneker C, Gough RP, Zwacka RM: MnSOD protects colorectal cancer cells from TRAIL-induced apoptosis by inhibition of Smac/DIABLO release. Oncogene 2008, 27:763-774.

41. Hietakangas V, Poukkula M, Heiskanen KM, Karvinen JT, Sistonen L, Eriksson JE: Erythroid differentiation sensitizes K562 leukemia cells to TRAIL-induced apoptosis by downregulation of c-FLIP. Mol Cell Biol 2003, 23:1278-1291

42. Klas C, Debatin KM, Jonker RR, Krammer PH: Activation interferes with the APO-1 pathway in mature human T cells. Int Immunol 1993, 5:625-630

43. Harper N, MacFarlane M: Recombinant TRAIL and TRAIL receptor analysis. Methods Enzymol 2008, 446:293-313.

44. Andrieu N, Salvayre R, Jaffrézou JP, Levade T: Low temperatures and hypertonicity do not block cytokine-induced stimulation of the sphingomyelin pathway but inhibit nuclear factor-kB activation. J Biol Chem 1995, 270:24518-24524.

doi:10.1186/1741-7007-9-18

Cite this article as: Tang et al:: The scavenging of superoxide radicals promotes apoptosis induced by a novel cell-permeable fusion protein, STRAIL:FeSOD, in tumor necrosis factor-related apoptosis-inducing ligand-resistant leukemia cells. BMC Biology 2011 9:18.

\section{Submit your next manuscript to BioMed Central and take full advantage of:}

- Convenient online submission

- Thorough peer review

- No space constraints or color figure charges

- Immediate publication on acceptance

- Inclusion in PubMed, CAS, Scopus and Google Scholar

- Research which is freely available for redistribution

Submit your manuscript at www.biomedcentral.com/submit
Biomed Central 